\title{
Experimental Assessment of the Performance of a Wedge Storage Solar Collector
}

\author{
Marwan Rija Jassim ${ }^{1}$, Omer Khalil Ahmed ${ }^{2}$, Öğr. Ü. Altuğ Karabey ${ }^{3}$ \\ \{marwanrija@gmail.com ${ }^{1}$, omerkalil@yahoo.com ${ }^{2}$, karabeyaltug@gmail.com ${ }^{3}$ \} \\ Van Yüzüncü Yil University, Turkey ${ }^{1,3}$, Northern Technical University, Iraq²
}

\begin{abstract}
This article includes a practical assessment of a novel design of the domestic solar collector and verification of its home uses, where the proposed model can be utilized as a water tank instead of the usual cubic and cylindrical tanks utilized in homes. This design is inspired by cutting the cylinder with two levels: a first level is a vertical plane and the second level is inclined with $45^{\circ}$. The experiments were conducted in two locations, the first in the Iraqi Kirkuk city $\left(35.47 \mathrm{~N}^{\circ}, 44.39^{\circ} \mathrm{E}\right)$, and the other in the Turkish van city $\left(38^{\circ} .5 \mathrm{~N}^{\circ}, 43.33^{\circ} \mathrm{E}\right)$. Two identical practical models were built for this purpose.
\end{abstract}

\begin{abstract}
The results of the article confirmed the average water temperature of the model under Iraqi weather conditions is higher than the water temperature of the collector in Turkish weather conditions. The results of the model under Iraqi weather conditions showed that the average water temperature reached about $53{ }^{\circ} \mathrm{C}$ at 5 p.m. Under load condition, the highest water temperature leaving the new collector was $47{ }^{\circ} \mathrm{C}$ at 4 p.m. in Kirkuk. The results confirmed that the average water temperature leaving the collector depends on the volume flow rate of water and the surrounding climatic conditions.
\end{abstract}

Keywords: Performance, wedge, storage, solar, collector.

\section{Introduction}

The danger of conventional energy depletion and associated pollution problems has prompted scientists to seek renewable and environmentally friendly energy sources[1]. Solar energy is a remarkable type of renewable energy that scientists began studying and designing to meet humanity's growing need for energy[2][3]. Solar energy is characterized by its availability in most of the countries of the world and its lack of advanced technology for its use. The primary utilization of solar energy is divided into three main uses: air heating, water heating, and electricity generation[4]. Solar water heaters are essential applications to achieve the domestic requirements of warm water, which depends on the sun as the main source instead of heaters that rely on electricity and fossil fuel that causes environmental pollution[5]. Conventional solar heaters consist of three essential parts: the flat plate solar collector, the storage tank, and the connecting pipes. The relatively high cost is the only obstacle to the widespread use of home solar heaters[6]. Researchers have been interested in studying low-cost heaters that are simple to install because of the high prices of the traditional solar heaters. To minimize the cost of the solar heater, scientists have developed another design for solar heaters that merges the three main parts of conventional heaters into one component. This invention is named the storage 
solar collector[7]. A storage solar collector gives a practical model for the utilization of solar water heating in multiple climates due to its simplicity. Many designs were presented recently for solar heaters. Kumar and Rosen[7] used a corrugated surface as an absorber surface to enhance the performance of the integrated storage solar collector. The use of the corrugated surface increases the area of the absorbent plate exposed to solar radiation, thereby increasing the amount of solar energy absorbed by the collector. Ahmed, O.[8] offered an interesting design of a storage solar collector, called the triangular storage collector, as in Fig. (1). The outcomes of the article confirmed that the daily efficiency without load was $48.7 \%$ during winter with 41 ${ }^{\circ} \mathrm{C}$ maximum water temperature. During summer, the daily efficiency was $62.2 \%$ with $57{ }^{\circ} \mathrm{C}$ maximum water temperature. At the continuous loading of the design, the system efficiency was $55.7 \%$ and $65.1 \%$ during winter and summer, respectively.

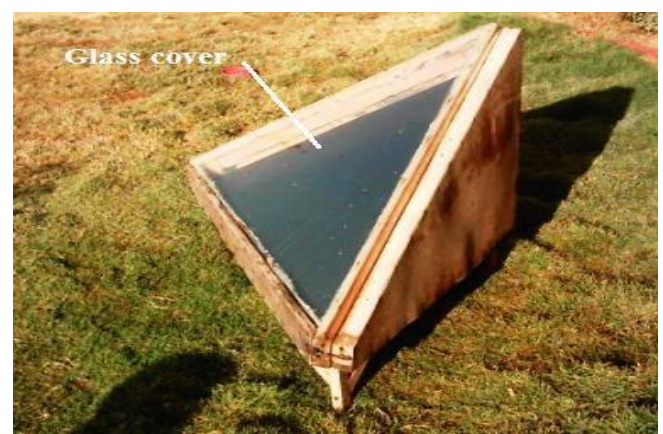

Fig. (1) Triangular storage collector [8]

Joudi et al.[9] offered a numerical investigation to assess the efficiency of the rectangular integrated collector using the ANSYS program as in Fig. (2). The results showed that the mean water temperature was $37^{\circ} \mathrm{C}$ in winter and $46^{\circ} \mathrm{C}$ in the summer. Also, an internal partition was inserted inside the space of the tank to evaluate its effect on the performance of the storage solar collector. The outcomes of the study indicated that the performance of the storage collector could be improved by using the partition.

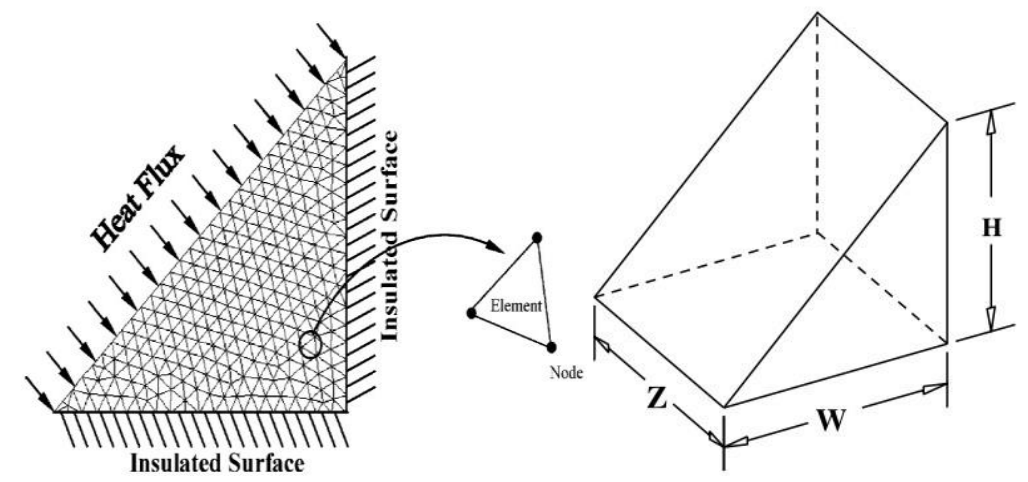

Fig. (2) Rectangular storage collector[9]

Ahmed[10] used the FLUENT program to study the performance of the wedge-shaped solar collector. The grid generation of the proposed design was built using the GAMBIT software. The tetrahedral element was used in this analysis as shown in Fig.3. The results of the CFD modelling confirmed that the maximum mean water temperature of the water was $18{ }^{\circ} \mathrm{C}$ and 
$41^{\circ} \mathrm{C}$ on $21^{\text {st }}$ December and $21^{\text {th }}$ June, respectively. Abdullah et al.[11] used the solar cells as an absorbent surface for the rectangular solar system shown in Fig.4. Thus, when the solar cell is cooled, its efficiency is increased and uses the exhausted heat energy to heat the water for domestic purposes. The outcome of this article showed that the temperature of the water leaving the collector reached the ultimate temperature of $42{ }^{\circ} \mathrm{C}$ at 2 p.m. With the new design, the difference in water temperature inside and outside of the solar heater was $4.6{ }^{\circ} \mathrm{C}$. In the summer, the total efficiency of the PV/water heater was $63.02 \%$ in the load case, while it was $37.75 \%$ without load condition. Taheri et al.[12] used a layer of the black coloured sands immersed into the water storage tank to enhance the performance of the solar collector. The daily thermal efficiency was higher than $70 \%$ and the maximum temperature of the stored water into the collector was about $90{ }^{\circ} \mathrm{C}$. Ahmed et al.[13] presented a practical study for the execution of the rectangular storage collector as in Fig.5.

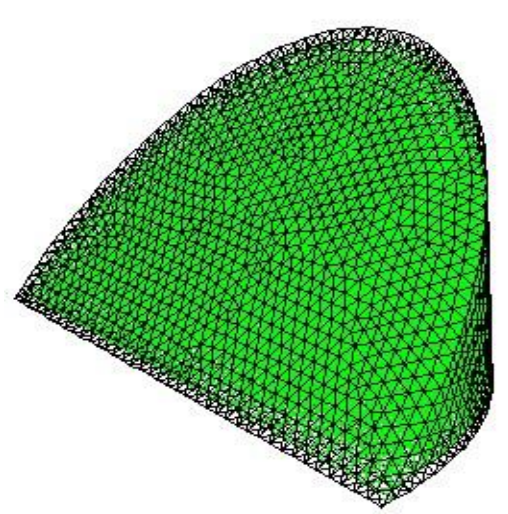

Fig.3 Numerical study of wedge collector[10]

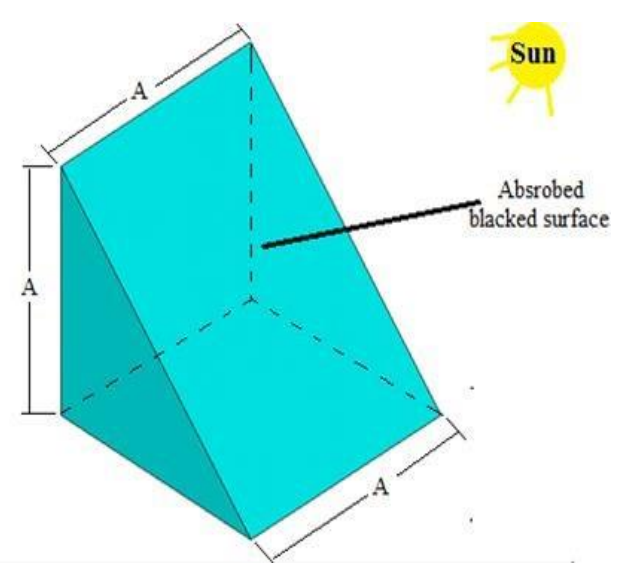

Fig.5 Rectangular storage solar collector[13]

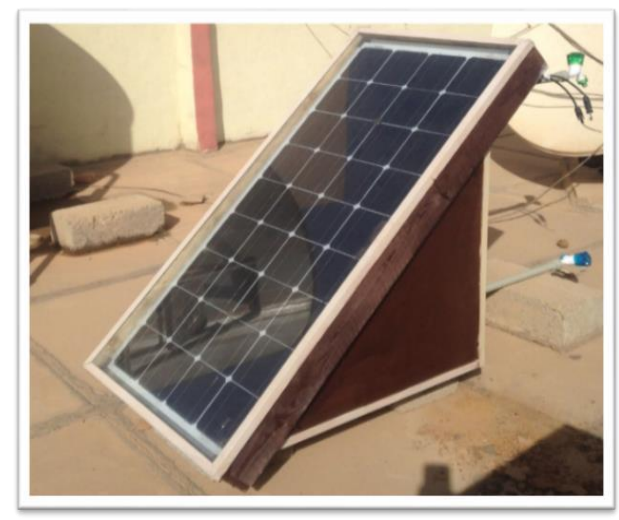

Fig.4 PV/storage collector [11]

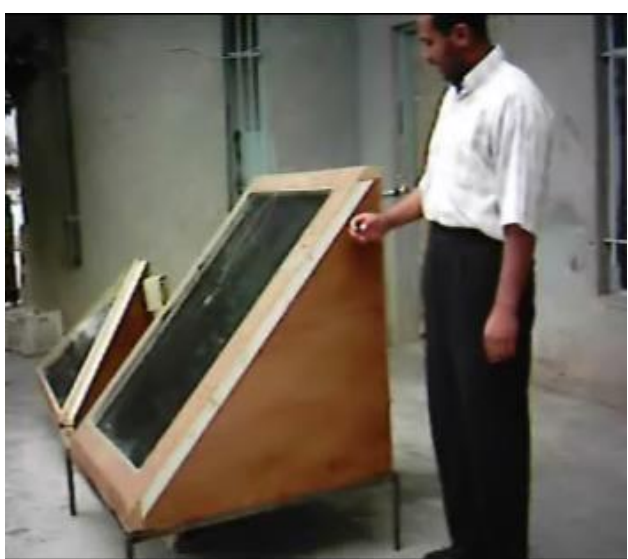

The experimental and numerical outcomes confirmed that the proportion of absorbed area to storage water volume is an essential factor that influences on the performance of this type of storage solar heater. The value of this ratio should be more than 12 to supply a sufficient amount of hot water for domestic applications. An exergetic efficiency analysis of a Photovoltaicthermal 
integrated system was studied by Radziemska[14]. The design illustrated in Fig. (6) was adopted in this article. The results show the exergetic efficiency is equal to $30.6 \%$, while the electrical efficiency is smaller due to the higher temperature of the PV module and equal to $11.1 \%$. Ziapour et al.[15] presented a new design using the combination of the integrated water collector with a solar panel system. Ziapour et al.[16][17] compared the operation of the four different absorber types of solar photovoltaic water heaters. The numerical outcomes confirmed that the absorber using aluminium fin absorber had the highest performance. Ahmed and Daoud[18] used a fuzzy logic technique to analyze the performance of wedge storage collector.

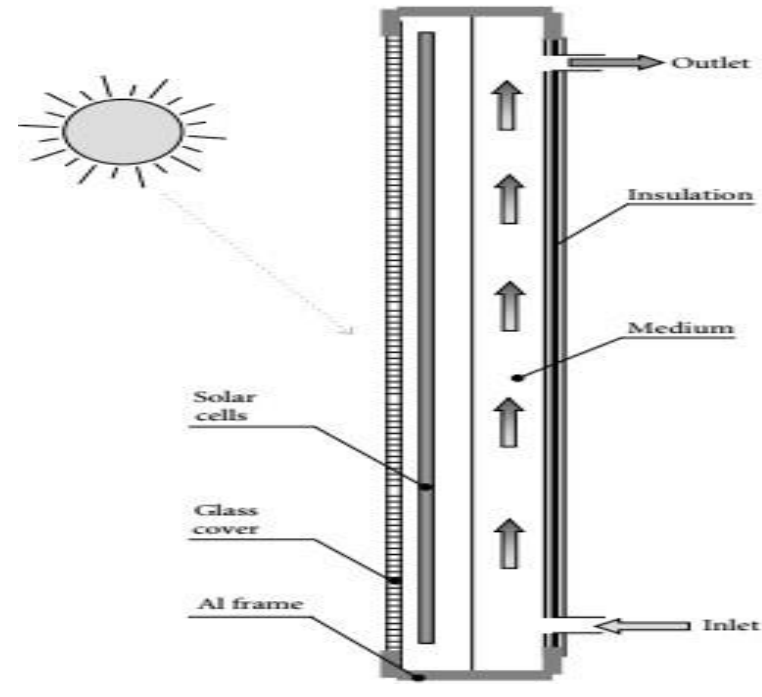

Fig. (3) Integrated PV/T collector was suggested by Radziemska[33]

A practical and numerical assessment was achieved on a cylindrical storage solar water heater (Fig.7) by Ahmed.O.K[19]. The cylindrical collector was suggested by cutting the cylinder at an inclined cutting plane. The experiments were conducted during the summer and winter months and under different operational conditions.

The current study aims to conduct a practical investigation to assess the performance of the wedge storage solar collector and verification of its home uses, where the proposed design is utilized as a water reservoir instead of the usual cubic and cylindrical tanks utilized in homes. The optimum declination angle to absorb solar energy in the winter period is 10 to $15^{\circ}$ more. The latitude angle for the middle-east region is approximately $45^{\circ}$; therefore, an appropriate inclination angle of $45^{\circ}$ which is appropriate for its simplicity. This design is inspired by cutting the cylinder with two levels: the first level is a vertical section and the second level is angled $45^{\circ}$ as in Fig. (8). This suggested design works as a solar collector and water reservoir in one part instead of the classical cubical or cylindrical tank generally utilized in Turkish and Iraqi homes. 


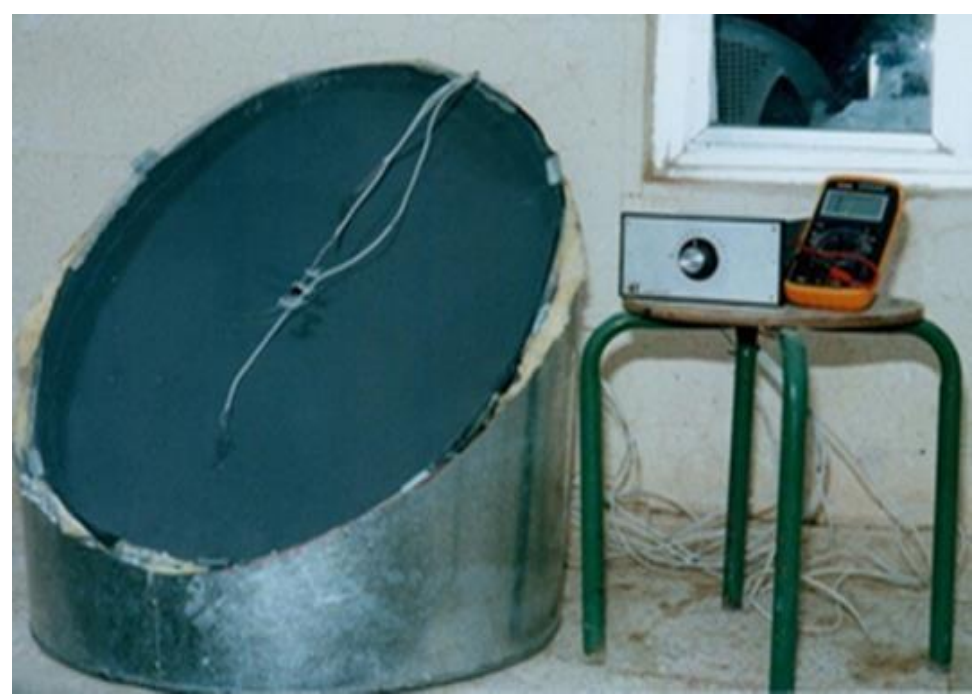

Fig. (7) A photograph of a cylindrical storage collector was presented by Ahmed [19]

\section{2- Methodology:}

The goal of this paper is to assess the performance of wedge solar storage collectors under the Turkish and Iraqi weather conditions. The experiments were conducted in two locations, the first in the Iraqi Kirkuk city $\left(35.47 \mathrm{~N}^{\circ}, 44.39^{\circ} \mathrm{E}\right)$, and the other in the Turkish van city $\left(38^{\circ} .5\right.$ $\left.\mathrm{N}^{\circ}, 43.33^{\circ} \mathrm{E}\right)$. Two similar models were built for this purpose. The recorded time from 9 a.m. to 5 p.m was conisdered for collecting experiemnetal data. The study starts by defining the testbed then the mathmaticalprocdeures to measure the performance and then ended with summarized conclusions.

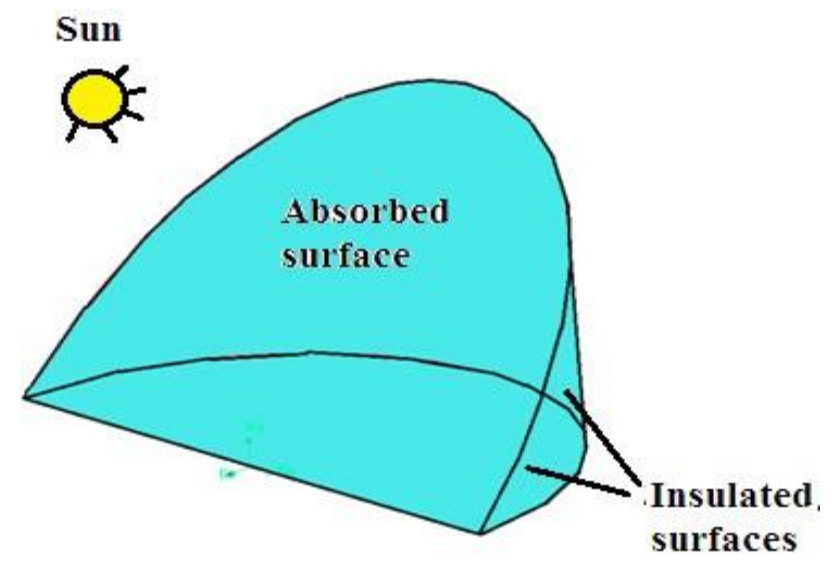

Fig.(8) The proposed design in the current study 


\section{Description of the Practical set-up:}

To assess the performance of a new design of a solar collector called a wedge storage solar collector, two practical set-ups were built in Turkey and Iraq. Each experimental apparatus consists of a half-cylinder cut at an angle of 45 degrees, as shown in Fig. (9), where the area of surface exposed to the sun is $0.562 \mathrm{~m}^{2}$. The height of the tank is $0.5 \mathrm{~m}$, while the radius of the tank was $0.5 \mathrm{~m}$, where it gives a volume of 98.17 litres.

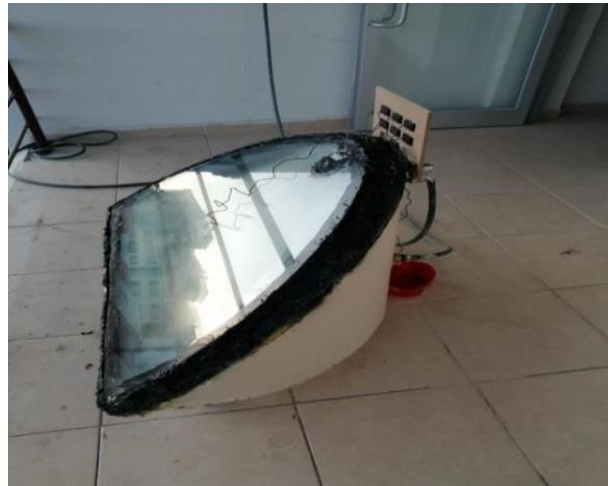

(a) Turkish model

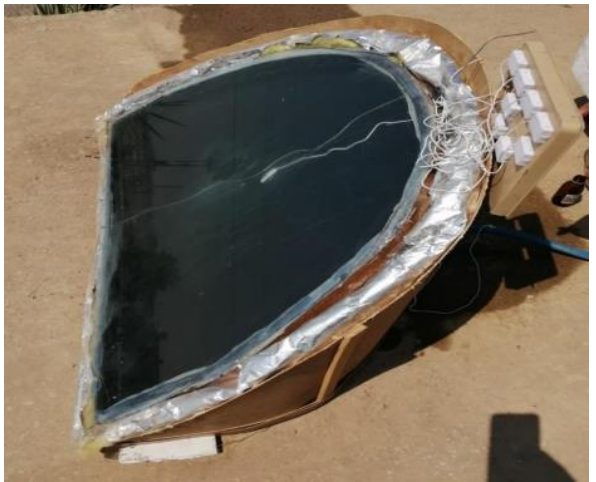

(b) Iraqi model

Fig. (9) Experimental set-up of wedge storage collector

Each model was manufactured from $3 \mathrm{~mm}$ thick ferrous metal sheets. The slanted surface is painted in a pale black colour to increase its absorption of solar radiation. To reduce thermal losses from the inclined surface, a glass layer of $4 \mathrm{~mm}$ thickness was installed at $3 \mathrm{~cm}$ from the inclined black surface within the optimum value for solar collectors[20]. The edges of the glass sheet were fixed using a special sealant to prevent external air in the space between the inclined black surface and the glass layer. The refractive index and extinction coefficient of glass sheet were taken as $1.53 \mathrm{~m}^{-1}$ and $0.025 \mathrm{~mm}^{-1}$, respectively[21]. The proposed design is connected to the cold-water source at the bottom and hot water is drawn from the top of the collector. The base of the model and the sides of the two models were isolated with good thermal insulation with a thermal conductivity of $0.8 \mathrm{~W} / \mathrm{m}^{2} .{ }^{\circ} \mathrm{C}[4]$. Measurement of the performance of solar systems depends on the measurement of temperatures; therefore different thermocouples were installed and distributed in 11 locations. Five thermocouples distributed inside the tank were installed as shown in Fig.10. Two thermocouples were utilized to sense the temperature of the in and out water from both systems. A thermocouple was used to determine the temperature of the black inclined surface and another thermocouple to determine the temperature of the glass layer. The amount of flowing water was measured using a rotameter. Before calibration, the flow meter was checked for scale formation inside the tube. Calibration of the flow meter was carried out using a stopwatch and graduated container. All the thermocouples utilized in the practical models were connected to a typical selector switch. The used thermocouples were 
calibrated relative to a standard mercury thermometer. To measure weather conditions such as solar radiation and wind speed, a particular weather station was used for this purpose. To evaluate the uncertainty in the experiments is very significant to check the validity of the performance. The uncertainty of the obtained results is computed using the one defined in [22].

\section{4 - Performance calculations:}

A series of experiments were conducted on the new stored solar collector as follows:

1- No-load conditions:

In this case, the tank is filled with water in the morning and no amount of water is withdrawn from it. The useful heat gain of a collector for no-load mode can be predicted using [23]:

$Q_{\text {useful }}=m c_{p}\left(T_{\text {meanF }}-T_{\text {means }}\right) / 3600$

Where $m$ and $C_{p}$ are the mass and heat of the water respectively. $T_{\text {meanF }}$ and $T_{\text {means }}$ are the average water tempertures at the end and begining of the hour respectively.

\section{2- Load conditions:}

In this case, the mass flow rate of load water was controlled by a globe valve at the inlet of the design. The mass flow rate of water was calculated by timing the water collected in a graduated cylinder. The energy collected with a load case was estimated from the following relation [24]:

$Q_{\text {useful }}=m c_{p}\left(T_{\text {meanF }}-T_{\text {means }}\right) / 3600+\dot{m} c_{p}\left(T_{O L}-T_{I L}\right)$

Where $\mathrm{T}_{\mathrm{OL}}$ and $\mathrm{T}_{\mathrm{IL}}$ are the outlet and inlet warter temperture respectively. $\dot{m}$ is the mass flow rate.

The hourly system efficiency of a novel design is simply the ratio of the useful energy to the total incoming solar energy as [25]:

$\eta=\frac{Q_{\text {useful }}}{A_{\text {col }} I_{\text {solar }}}$

Where $\mathrm{A}_{\mathrm{col}}$ and $\mathrm{I}_{\text {solar }}$ are absorbed are and solar radiation into the inclind surface.

\section{5- Results and discussion:}

To assess the performance of the proposed design, two laboratory models were built; one of them was tested under Iraqi weather conditions and the other was under Turkish weather conditions. The two models were directed to the south to absorb the most significant amount of solar energy. At the beginning of each day, the glass cover is cleaned of dust, and readings are recorded every hour from eight in the morning until five in the evening. The results were divided into two parts, the first part is test results in the Iraqi Kirkuk city $\left(35.47 \mathrm{~N}^{\mathrm{o}}, 44.39{ }^{\circ} \mathrm{E}\right)$, and the second part is test results in the Turkish Van city $\left(38^{\circ} .5 \mathrm{~N}^{\circ}, 43.33^{\circ} \mathrm{E}\right)$. 


\section{5-1 Results of the storage collector under Iraqi weather conditions:}

The value of solar radiation for Kirkuk city was shown in Fig. (10) of the $1^{\text {st }}$ of September. The ultimate value of solar radiation was $974 \mathrm{~W} / \mathrm{m}^{2}$ at noon. The average storage temperature is the most important factor that determines the performance of the storage solar heater. This factor is evaluated from the relation:

$T_{\text {storage }}=\frac{\sum_{i=1}^{n} M_{i} * T_{i}}{M_{\text {total }}}$

Where Mi and Ti are the ith mass of slice and temperture respectively.

Fig. (11) clarifies the change of average storage temperature during the day under the Iraqi weather conditions for no-load pattern, it is noticed that the $\mathrm{T}_{\text {storage }}$ temperature changes from the early morning hours to reach its highest value of $53{ }^{\circ} \mathrm{C}$ at $5 \mathrm{p} . \mathrm{m}$. on the $3^{\text {rd }}$ September. While the top value of the $\mathrm{T}_{\text {storage }}$ temperature was $32^{\circ} \mathrm{C}$ on $18^{\text {th }}$ December under the same conditions of loading, it is also noticed that the storage water temperature increases during the first half of the day due to the increase in the value of absorbed solar radiation. It then decreases thereafter because of solar radiation reduced and thermal losses incraed at the collector front side.

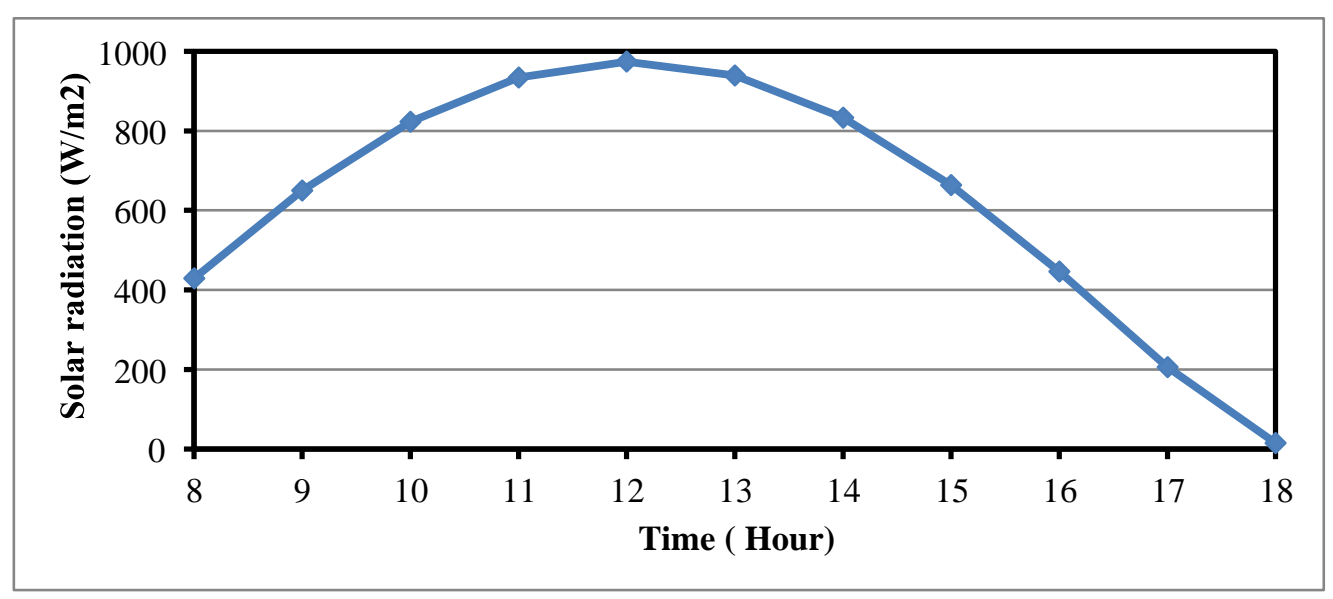

Fig. ( 10 ) Variation of solar radiation for Kirkuk city 


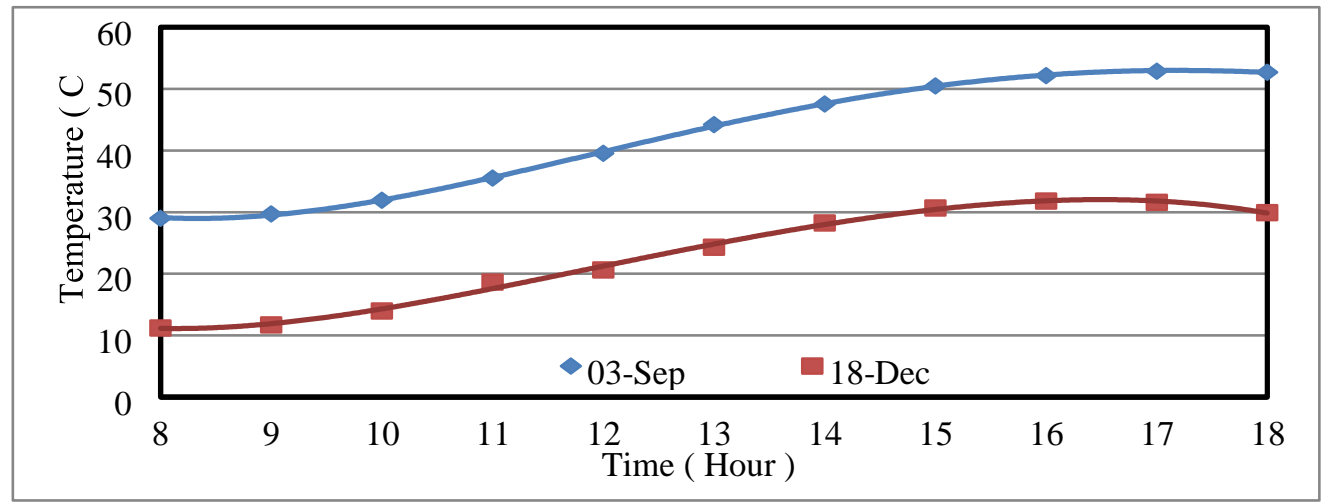

Fig. (11) Variation of storage temperature of the collector without load under Iraqi weather conditions

The highest expected value of the water temperature inside the storage collector is located at the top of the collector due to the phenomenon of natural convection. It is noted in Fig. (12) that the practical values of the maximum water temperature at the top of this tank reaches this highest value at $4 \mathrm{pm}$ and then decreases after that for both days. The maximum water temperature at the top of the collector was $73{ }^{\circ} \mathrm{C}$ and $54{ }^{\circ} \mathrm{C}$ of $3^{\text {rd }}$ September and $18^{\text {th }}$ December. This trend is traditional for storage solar collectors[26][27].

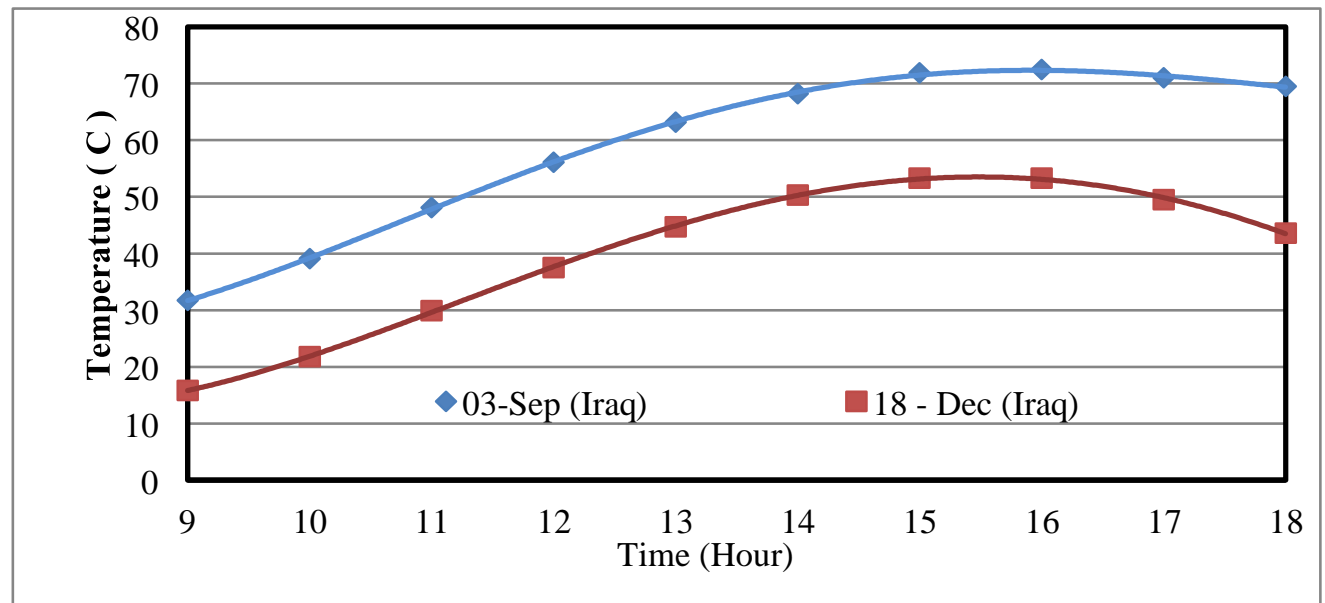

Fig. (12) Variation of maximum water temperature of the collector without load under Iraqi weather conditions

Hot water drawn was continuously taken at two different rates $(0.2$ litres/min and 0.4 litres/min) based on some practical tests. The mass flow rate and temperature of the water were both measured. This is achieved by access the cold water at the bottom of the collector whereas hot water emtyed from the top.

Fig. (13) shows the variation of the system temperatures when the flow rate was 0.2 litres/min. It is noticed that the $\mathrm{T}_{\text {storage }}$ and $\mathrm{T}_{\mathrm{OL}}$ temperatures are increasing throughout the period between 8 a.m. and 4 p.m., which confirmed that the absorbed solar energy is higher than that exhausted by the hot water. After 4 p.m., these temperatures start to decline due to the absorbed 
solar energy being lower than the energy drained by the hot water. The highest temperature of the water leaving the collector was $47^{\circ} \mathrm{C}$ at 4 p.m. The same behaviour of system temperatures was recorded when the volume flow rate was $(0.4$ litres $/ \mathrm{min})$ as shown in Fig. (14). The average temperature of the water leaving the collector was $44{ }^{\circ} \mathrm{C}$ at 3 p.m. Results similar to the current results were recorded in several studies as[28][13][29].

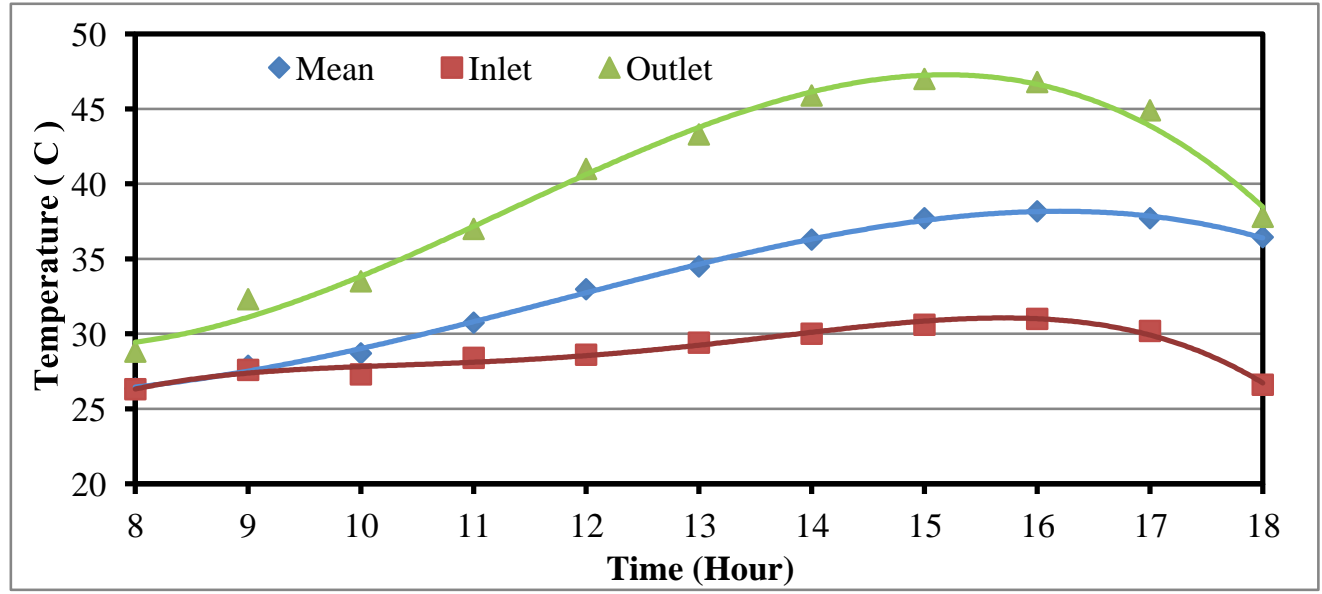

Fig. ( 13 ) Effect of load (0.2 litre/min) on the system temperature under Iraqi weather conditioning

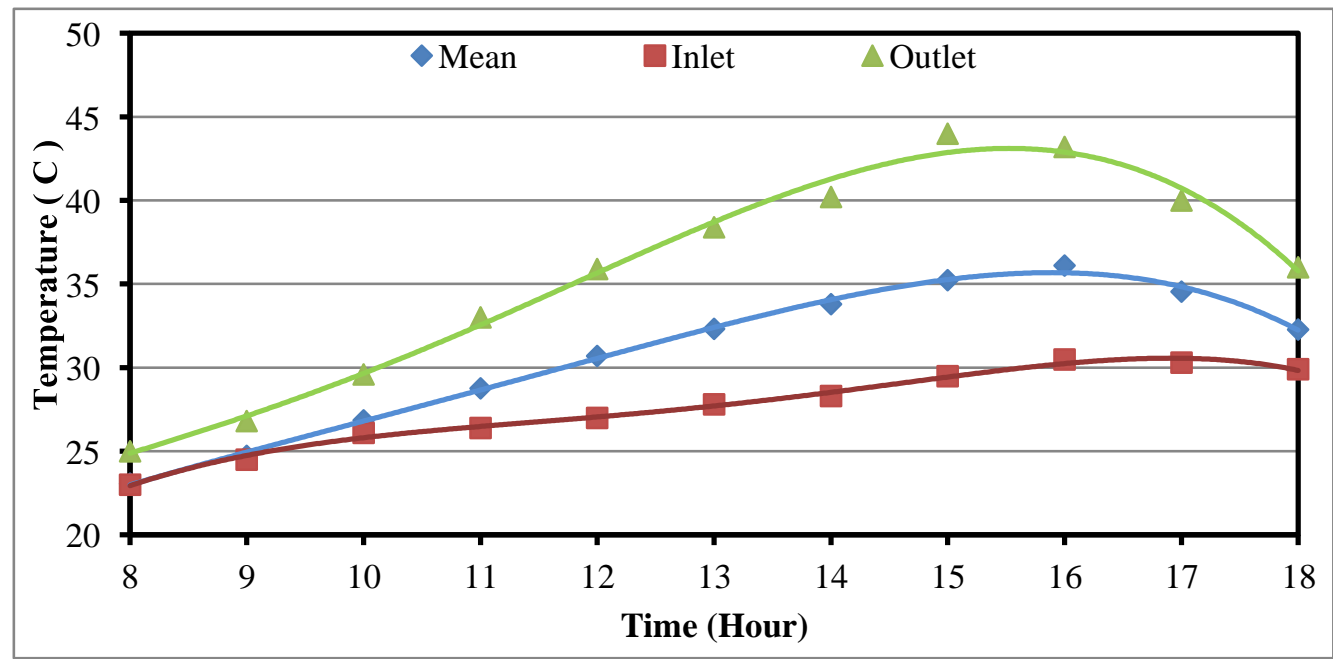

Fig. (14) Effect of load (0.4 litres/min) on the system temperature under Iraqi weather conditioning

\section{5-2 Results of the storage collector under Turkish weather conditions:}

The value of solar radiation for Van city was shown in Fig. (15) on the $22^{\text {nd }}$ of September. The ultimate noon solar radiation was $954 \mathrm{~W} / \mathrm{m}^{2}$. Fig. (16) illustrates the change of average water temperature during the day under the Turkish weather conditions for no-load pattern, it is clear that the average storage temperature changes from the early morning hours to reach its 
maximum value of $29^{\circ} \mathrm{C}$ at 5 p.m. on $22^{\text {nd }}$ November. Fig. (17) shows a comparison between the water temperatures at the top of the tank for the two models. It is noted that the temperature in Iraq is higher than in Turkey due to the high values of solar radiation in Iraq. Fig. (18) shows the behaviour of the system temperatures when the flow rate of water mass was $0.2 \mathrm{litres} / \mathrm{min}$ under the Turkish weather conditions. It is observed that $\mathrm{T}_{\text {storge }}$ and $\mathrm{T}_{\mathrm{OL}}$ temperatures rises between 9 a.m. and 2 p.m., that confirmed the absorbed solar energy is higher than that exhausted by the hot water. After 2 p.m. these temperatures start to decrease because the absorbed solar energy was lower than the energy exhausted by the hot water. The highest temperature of the water leaving the collector was $32^{\circ} \mathrm{C}$ at $2 \mathrm{p} . \mathrm{m}$. The same behaviour of system temperatures was recorded when the volume flow rate was $(0.4$ litre $/ \mathrm{min})$ for the Turkish model as in Fig. (19). The maximum value of the $T_{\text {average }}$ temperature of the water leaving the collector was $30^{\circ} \mathrm{C}$ at 3 p.m.

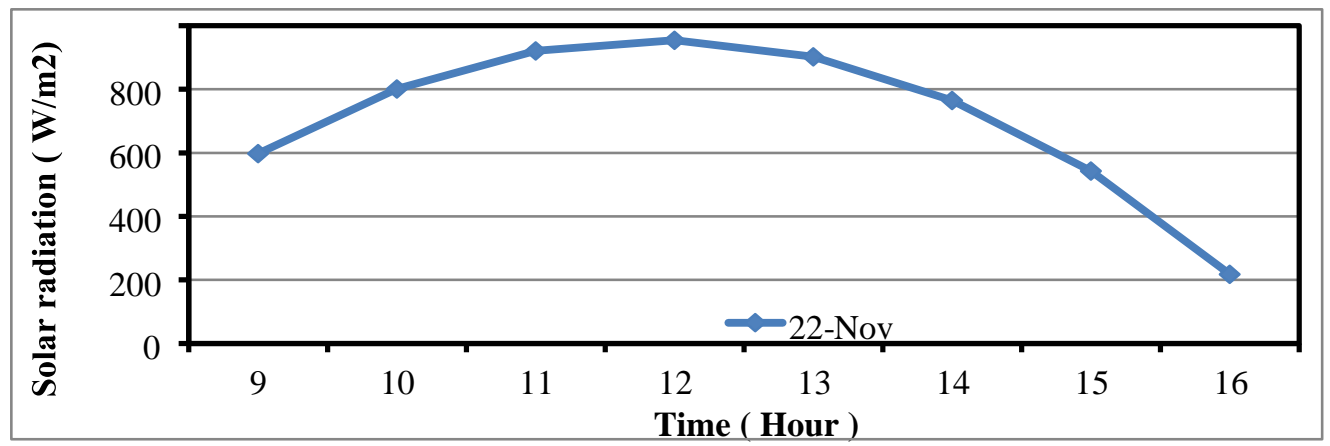

Fig. ( 15 ) Variation of solar radiation for Van city

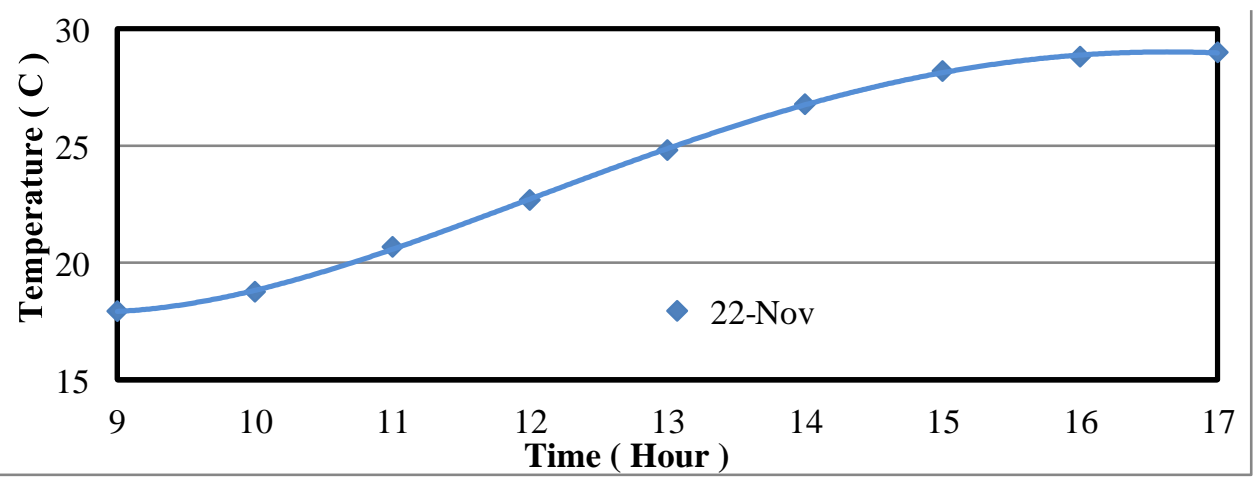

Fig. (16) Variation of mean water temperature without load under Turkish weather conditions 


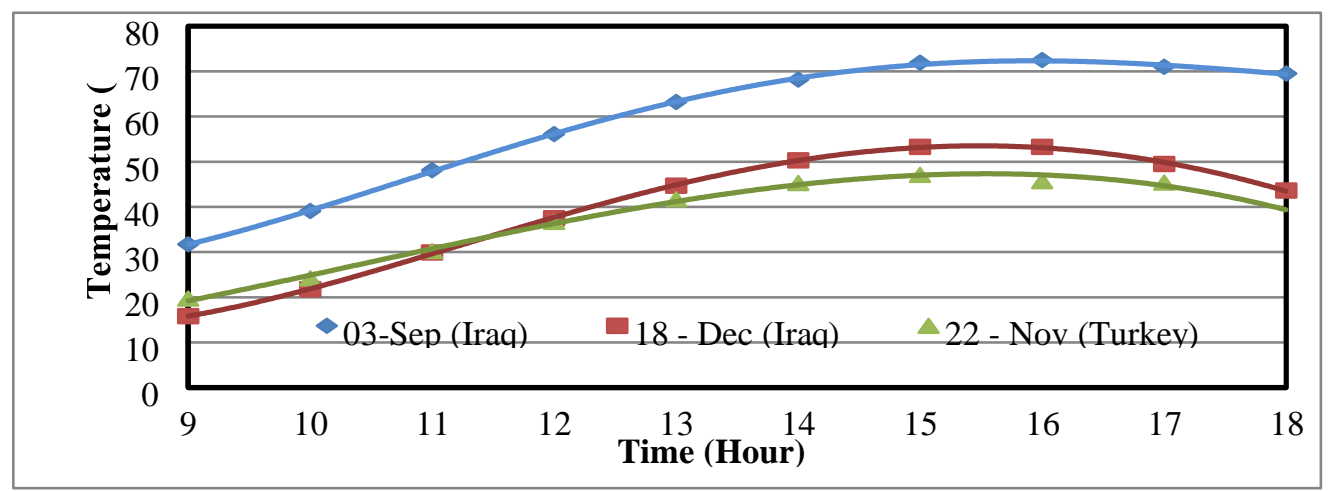

Fig.(17) Maximum water temperature changes without load under Iraqi and Turkish weather conditions

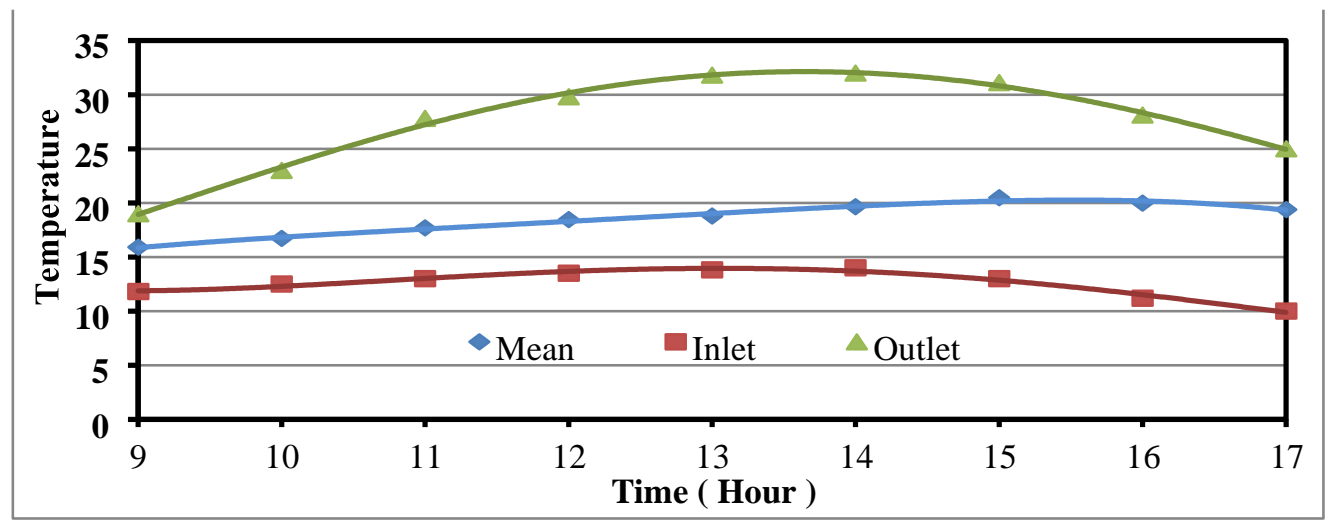

Fig. ( 18 ) Effect of load (0.2 litres/min) on the system temperature under Turkish weather conditioning

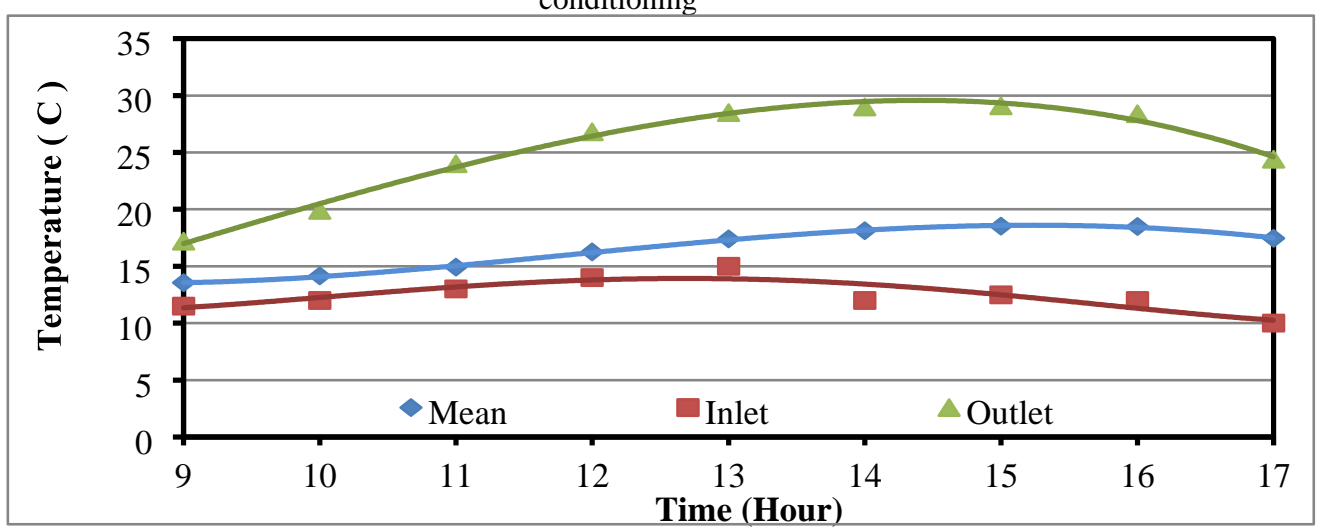

Fig. ( 19 ) Effect of load (0.4 litres/min) on the system temperature under Turkish weather conditioning

\section{6- Summrized Conclusions:}

Based on our achieved results, the following points can be concluded: 
1- Use the wedge solar collector as a water tank and a solar heater at the same time in homes.

2 - The highest water temperature leaving the collector at $47^{\circ} \mathrm{C}$ at 4 p.m. when the volume flow rate was $(0.2$ litres/min $)$ under the Iraqi weather conditions. The same behaviour of system temperatures was recorded when the volume flow rate was ( 0.4 litres $/ \mathrm{min})$.

3- The temperature of the outgoing water and stored water increased from 9 a.m. until 4 p.m, which confirmed that the absorbed solar energy is higher than that exhausted by the hot water.

\section{7- References:}

[1] O. K. Ahmed and s. M. Bawa, "The combined effect of nanofluid and reflective mirrors on the performance of PV/thermal Solar collector,” Therm Sci, vol. 23, no. 2A, pp. 573-587, 2019.

[2] Somov, A. Wildfire safety with wireless sensor networks. EAI Endorsed Transactions on Ambient Systems. pp. 1-11 (2011)

[3] O. K. Ahmed, K. I. Hamada, and A. M. Salih, "Performance analysis of PV/Trombe with water and air heating system: an experimental and theoretical study," Energy Sources, Part A Recover Util Environ Eff, vol. 86, no. 0, pp. 716-722, 2019.

[4] O. Khalil Ahmed and Z. Aziz Mohammed, "Influence of porous media on the performance of hybrid PV/Thermal collector,” Renew Energy, vol. 112, pp. 378-387, 2017.

[5] O. K. Ahmed, K. I. Hamada, and A. M. Salih, "Enhancement of the performance of

[6] Photovoltaic / Trombe wall system using the porous medium: Experimental and theoretical study," Energy, vol. 171, pp. 14-26, 2019.

[7] O. K. Ahmed, Kk. I. Hamada, A. M. Salih, and R. W. Daoud, "A state of the art review of PVTrombe wall system: Design and applications," Environmental Prog Sustain energy, no. October, pp. 1-16, 2019.

[8] O. K. Ahmed and S. M. Bawa, "Reflective mirrors effect on the performance of the hybrid PV/thermal water collector," Energy Sustain Dev, vol. 43, pp. 235-246, 2018.

[9] R. Kumar and M. A. Rosen, "Thermal performance of integrated collector storage solar water heater with corrugated absorber surface," Appl Therm Eng, vol. 30, no. 13, pp. 1764-1768, 2010.

[10] O. K. Ahmed, "A numerical and experimental investigation for a triangular storage collector," Sol Energy, vol. 171, no. June, pp. 884-892, 2018.

[11] K. A. Joudi, I. A. Hussein, and A. A. Farhan, "Computational model for a prism-shaped storage solar collector with a right triangular cross-section," Energy Convers Manag, vol. 45, no. 3, pp. 391-409, 2004.

[12] O. K. Ahmed, "Assessment of the Performance for a New Design of Storage Solar Collector," Int J Renew Energy Res, vol. 8, no. 1, pp. 250-257, 2018.

[13] A. H. Abdullah, O. K. Ahmed, and Z. H. Ali, "Performance analysis of the new design of photovoltaic/storage solar collector," Energy Storage, vol. 1, no. 3, pp. 1-13, 2019.

[14] Y. Taheri, B. M. Ziapour, and K. Alimardani, "Energy Conversion and Management Study of an efficient compact solar water heater," Energy Convers Manag, vol. 70, pp. 187-193, 2013.

[15] O. K. Ahmed, R. W. Daoud, and O. T. Mahmood, "Experimental Study of a Rectangular Storage Solar Collector with a numerical analysis," in IOP Conference Series: Materials Science and Engineering, 2019, pp. 1-14. 
[16]E. Radziemska, "Performance Analysis of a Photovoltaic-Thermal Integrated System," Int J photo energy, vol. 2009, pp. 1-6, 2009.

[17] B. M. Ziapour, V. Palideh, and A. Mohammadnia, "Study of an improved integrated collectorstorage solar water heater combined with the photovoltaic cells," Energy Convers Manag, vol. 86, pp. 587-594, 2014.

[18] B. M. Ziapour and A. Aghamiri, "Simulation of an enhanced integrated collector - storage solar water heater," Energy Convers Manag, vol. 78, pp. 193-203, 2014.

[19] B. M. Ziapour, V. Palideh, and M. Baygan, "Performance comparison of four passive types of photovoltaic - thermal systems," ENERGY Convers Manag, vol. 88, pp. 732- 738, 2014.

[20] O. K. Ahmed and R. W. Daoud, "Determining the Coefficients of the Wedge Storage Solar Collector Based on Fuzzy Logic," in 2018 International Conference on Engineering Technologies and their Applications (ICETA), 2018, pp. 7-12.

[21] O. Khalil Ahmed, "Experimental and numerical investigation of cylindrical storage collector (case study)," Case Stud Therm Eng, vol. 10, pp. 362-369, 2017.

[22] J. A. Duffie and W. A. Beckman, Solar Engineering of Thermal Processes, Fourth ed. John Wiley \& Sons, Inc., 2013.

[23] O. K. Ahmed and Z. A. Mohammed, "Dust effect on the performance of the hybrid PV/Thermal collector," Therm Sci Eng Prog, vol. 3, pp. 114-122, Feb. 2017.

[24] J. P. Holman, Experimental methods for engineers, vol. 9, no. 2. 1994.

[25] O. K. Ahmed, "Effect of Dust on the Performance of Solar Water Collectors in Iraq," Int J Renew Energy Dev, vol. 5, no. 1, pp. 65-72, 2016.

[26] M. Chaabane, H. Mhiri, and P. Bournot, "Thermal Performance of an integrated collector storage solar water heater (ICSSWH) with phase change materials (PCM)," Energy Convers Manag, vol. 78, pp. 897-903, 2014.

[27] M. Souliotis, D. Chemisana, Y. G. Caouris, and Y. Tripanagnostopoulos,

[28] "Experimental study of integrated collector storage solar water heaters," Renew Energy,

[29] vol. 50, pp. 1083-1094, 2013.

[30] B. Vaxman and M. Sokolov, "Experiments with an integral compact".

[31] SOLAR HEATER,” Sol Energy, vol. 34, no. 6, pp. 447-454, 1985.

[32] R. Shukla, K. Sumathy, P. Erickson, and J. Gong, "Recent advances in the solar water heating systems: A review,” Renew Sustain Energy Rev, vol. 19, pp. 173-190, 2013.

[33] O. K. Ahmed, "Assessment the Performance of the Triangular Integrated Collector," Sci J Univ Zakho, vol. 6, no. 4, pp. 171-176, 2018. 